\title{
KEJADIAN DIARE PADA BALITA BERDASARKAN KONDISI JAMBAN DI DUSUN BONJERUK WILAYAH KERJA UPTD PUSKESMAS BONJERUK LOMBOK TENGAH
}

\author{
Ni Made Sumartyawati ${ }^{1}$, Anggi Rindang Qorian ${ }^{2}$, Novi Enis Rosuliana ${ }^{3}$, \\ Suhartining $\operatorname{sih}^{4}$ \\ ${ }^{1,2,3,4}$ Sekolah Tinggi Ilmu Kesehatan (STIKES) MAtaram \\ langitku240615@gmail.com
}

\begin{abstract}
Background: The highest increase in diarrhea in the UPTD Puskesmas Bonjeruk occurred in Dusun Bonjeruk where most of the sufferers were toddlers.

Methods: This study is a quantitative study with a correlational study design that uses a cross sectional approach. Samples were obtained as many as 52 mothers who have children under five and live in the village of Bonjeruk which is determined by total sampling. The assessment of the latrine condition used an observation sheet, while the incidence of diarrhea was obtained based on interviews with direct respondents. Measuring the correlation using the Chi-Square analysis test with a confidence degree of 0.05 .

Results: From the study, it was found that 31 (59.6\%) children under five had diarrhea with healthy latrines as many as 46 (88.5\%). The 2-tailled sig value from the ChiSquare test is 0.001, so the sig. 2-tailled is less than alpha.

Conclusion: This study shows that there is a significant relationship between latrine conditions and the incidence of diarrhea in children under five. The community continues to improve the maintenance of healthy latrines through the attention of the puskesmas.
\end{abstract}

Key words: latrine condition, diarrhea incidence, under five

\begin{abstract}
ABSTRAK
Latar Belakang: Peningkatan tertinggi diare di wilayah UPTD Puskesmas Bonjeruk terjadi pada Dusun Bonjeruk dengan sebagian besar penderitanya adalah balita.

Metode: Penelitian ini adalah penelitian deskriptif korelasional yang menggunakan pendekatan cross sectional. Sampel didapatkan sebanyak 52 orang ibu yang mempunyai balita dan tinggal di dusun Bonjeruk yang ditentukan dengan total sampling. Penilaian kondisi jamban menggunakan lembar observasi, sedangkan kejadian diare didapatkan berdasarkan wawancara kepada responden langsung. Mengukur korelasi menggunakan uji analisis Chi-Square dengan derajat kepercayaan 0,05.

Hasil: dari penelitian didapatkan $31(59,6 \%)$ balita mengalami diare dengan kondisi jamban sehat sebanyak $46(88,5 \%)$. Nilai sig 2-tailled dari uji Chi-Square sebesar 0,001, sehingga sig. 2-tailled lebih kecil dari alpha.

Kesimpulan: Penelitian menunjukkan ada hubungan yang signifikan antara kondisi jamban dengan kejadian diare pada balita. Peningkatan pemeliharaan jamban sehat tetap dilakukan oleh masyarakat melalui perhatian puskesmas.
\end{abstract}

Kata kunci : kondisi jamban, kejadian diare, balita 


\section{PENDAHULUAN}

Derajat kesehatan merupakan salah satu faktor yang sangat berpengaruh pada kualitas sumber daya manusia yang lebih produktif dan meningkatkan daya saing manusia (WHO, 2014). Tujuan pembangunan kesehatan menuju Indonesia Sehat 2025 adalah meningkatnya kesadaran, kemauan, dan kemampuan hidup sehat bagi setiap orang. Peningkatan derajat kesehatan masyarakat yang setinggi-tingginya dapat terwujud melalui terciptanya masyarakat, bangsa dan negara Indonesia yang ditandai oleh penduduknya yang hidup dengan perilaku dan dalam lingkungan sehat, memiliki kemampuan untuk menjangkau pelayanan kesehatan yang bermutu, secara adil dan merata

Berdasarkan data dari World Health Organization (WHO) pada tahun 2013 diperkirakan sebesar 1,1 milyar orang atau $17 \%$ penduduk dunia masih Buang Air Besar (BAB) di area terbuka, dari data tersebut sebesar $81 \%$ penduduk yang Buang Air Besar Sembarangan (BABS) terdapat di 10 negara yaitu India $(58 \%)$, Indonesia $(12,9 \%)$, China $(4,5 \%)$, Ethiopia (4,4\%), Pakistan (4,3\%), Nigeria (3\%), Sudan (1,5\%), Nepal $(1,3 \%)$, Brazil $(1,2 \%)$ dan Nigeria $(1,1 \%)$ (WHO, 2014).

Berdasarkan konsep dan definisi Milenium Development Goals (MDGs) yang pada tahun 2016 dilanjutkan dengan Sustainable Development Goals (SDGs), rumah tangga dikatakan memiliki akses sanitasi layak apabila fasilitas sanitasi yang digunakan memenuhi syarat kesehatan antara lain dilengkapi dengan leher angsa, tanki septic (septic tank)/Sistem Pengolahan Air Limbah (SPAL) yang digunakan sendiri atau bersama. Persentase rumah tangga di Indonesia yang memiliki akses terhadap sanitasi layak tahun 2013 yaitu $60,05 \%$ tahun $2014(61,08 \%)$ dan tahun
2015 meningkat menjadi 62, 14\% (Kemenkes RI, 2015).

Air bersih dan sanitasi layak adalah kebutuhan dasar manusia. Salah satu poin dalam tujuan pembangunan berkelanjutan Sustainable Development Goals (SDGs) pada sektor lingkungan hidup adalah memastikan masyarakat mencapai akses universal air bersih dan sanitasi dasar yaitu jamban sehat. Sasaran global dari poin tersebut yaitu tahun 2030 masyarakat telah mencapai akses terhadap sanitasi dan kebersihan yang memadai dan merata serta menghentikan praktik buang air besar di tempat terbuka. Di Sumatra Selatan, pada tahun 2013 persentase rumah tangga yang memiliki akses terhadap sanitasi layak tinggi yaitu 58,29\%, namun mengalami kenaikan pada tahun 2014 menjadi 59,79\% dan pada tahun 2015 meningkat menjadi $61,30 \%$. Provinsi dengan persentase rumah tangga yang memiliki akses terhadap sanitasi layak tinggi yaitu Daerah Khusus Ibukota (DKI) Jakarta dan akses terendah yaitu papua disetiap tahunnya (Kemenkes RI, 2016). Berdasarkan profil kesehatan dinas kesehatan kabupaten atau kota tahun 2011-2016 terlihat bahwa cakupan penanganan diare di provinsi NTB tahun 2016 mengalami sedikit penurunan sebanyak 61.13 jika dibandingkan dengan tahun 2015 sebanyak 77.20, hal ini disebabkan oleh tingginya angka perkiraan kasus diare menjadi lebih tinggi karena adanya perubahan angka kesakitan diare pada tahun 2016 sebanyak 161,686, yaitu 270/1000 penduduk (Dikes Provinsi NTB, 2017).

Hidup sehat adalah kebersihan lingkungan yang tidak tercemar oleh kotoran seperti tinja yang di area lingkungan sekitar. Syarat jamban sehat sesuai kaidah-kaidah kesehatan adalah masyarakat tidak mencemari sumber air minum, berbau tinja dan tidak bebas 
dijamah oleh serangga maupun tikus,air seni,air bersih dan air pengelontor tidak mencemari tanah sekitar oleh karena itu lantai, setidaknya berukuran $1 \times 1$ meter dan dibuat cukup landai, miring kearah blobang jongkok, selain itu mudah dibersihkan,aman penggunaannya, dilengkapi dengan dinding dan penutup, cukup penerangan dan sirkulasi udara,luas ruangan yang cukup dan tersedia air dan alat pembersih ( Amelia, 2014).

Jamban merupakan fasilitas pembuangan tinja yang efektif untuk memutuskan mata rantai penularan penyakit. Penggunaan jamban tidak hanya nyaman melainkan juga turut melindungi dan meningkatkan kesehatan keluarga dan masyarakat. Dengan bertambahnya jumlah penduduk yang tidak sebanding dengan area pemukiman yang ada, masalah mengenai pembuangan kotoran manusia menjadi meningkat, dilihat dari segi kesehatan masyarakat, masalah pembuangan kotoran manusia merupakan masalah pokok untuk sedini mungkin diatasi (Notoatmodjo, 2005).

Diare adalah gangguan buang air besar/BAB lebih dari 3 kali sehari dengan konsistensi tinja cair, dapat disertai dengan darah dan atau lendir. Diare merupakan salah satu masalah kesehatan terbesar di masyarakat, penyakit yang berbasis lingkungan terutama karena masih buruknya kondisi sanitasi dasar, lingkungan fisik maupun rendahnya prilaku masyarakat untuk hidup sehat. Penyakit diare dapat berakibat fatal dan menjadi penyakit berbahaya karena dapat menyebabkan kematian dan menimbulkan kejadian luar biasa (KLB) (Dikes Provinsi NTB, 2017).

Penyebab diare adalah Pencemaran sumber air bersih masyarakat oleh tinja disebabkan kebiasaan masyarakat untuk membuang kotoran sembarangan ataupun jamban yang tidak memenuhi standar, ditambah lagi dengan konstruksi sumur, yang merupakan sumber air bersih sebagian besar masyarakat, tidak memenuhi syarat kesehatan kemudian dapat menjadi faktor determinan dari kejadian diare di masyarakat, (Melviana, dkk; 2014).

Penyakit diare masih sering menimbulkan Kejadian Luar Biasa (KLB) dengan jumlah penderita yang banyak dalam waktu yang singkat. Namun dengan tata laksana diare yang cepat, tepat dan bermutu kematian dapat ditekan seminimal mungkin. Diare merupakan penyebab kedua terbesar kematian balita di dunia. Penyakit ini bisa dicegah dan diobati, menurut data World Health Organization (WHO) ada sekitar empat miliar kasus diare akut setiap tahun dengan mortalitas 3-4 juta pertahun milliar kasus setiap tahunnya.Diare sering kali dianggap sebagai masalah yang sepele, padahal di tingkat global dan nasional fakta menunjukkan sebaliknya World Health Organization (WHO) (Ibrahim,dkk; 2012)

\begin{tabular}{|c|}
\hline $\begin{array}{l}\text { Dampak } \\
\text { Diare }\end{array} \begin{array}{r}\text { dapat } \\
\text { mengakibatkan kehilangan } \\
\text { ditubuh (dehidrasi) dan jika tidak } \\
\text { ditangani secara cepat dehidrasi dapat } \\
\text { berakibat lebih fatal lagi. Selain itu, } \\
\text { defekasi yang terjadi secara terus } \\
\text { menerus mengakibatkan terjadinya } \\
\text { pembuangan zat-zat nutrisi sebelum } \\
\text { sempat diserap oleh tubuh, padahal zat- } \\
\text { zat tersebut dibutuhkan oleh tubuh untuk } \\
\text { proses metabolisme yang terus } \\
\text { berlangsung serta untuk membantu } \\
\text { tubuh memulihkan kondisi dan untuk } \\
\text { pertahanan tubuh terhadap kuman } \\
\text { termasuk penyebab diare itu sendiri. } \\
\text { Oleh sebab itu, kasus diare harus bisa } \\
\text { dicegah terutama pada individu yang } \\
\text { rentan seperti bayi dan balita, ibu hamil } \\
\text { serta lansia (Melviana, dkk; 2014). } \\
\text { Berdasarkan data Kemenkes RI }\end{array}$ \\
\hline
\end{tabular}


bulan yaitu sebesar (21,65\%) lalu kelompok umur 12-17 bulan sebesar (14,5\%), kelompok umur 24-29 bulan sebesar $(12,37 \%)$. Hal ini merupakan maslah kesehatan yang perlu diperhatikan terutama diare yang umumnya diderita bayi dan balita dapat menjadi penyumbang kematian terbesar. Factor kebersihan diri dan sanitasi lingkungan, kesadaran orang tua untuk berplikaku hidup bersih dan sehat serta pemberian ASI menjadi factor yang openting dalam penurunan angka kesakitan diare pada bayi dan balita,

Berdasarkan jurnal penelitian Novitry \& Agustin (2017), terdapat hubungan yang bermakna antara pendidikan responden terhadap kepemilikan jamban sehat dimana responden yang memiliki jamban namun dalam kategori tidak sehat dalam sebagian besar $(79,8 \%)$ adalah responden yang termasuk dalam kategori pendidikan rendah. kenyataan dimasyarakat menunjukkan bahwa responden dengan tingkat pendidikan yang rendah akan sulit memahami pesan atau informasi yang disampaikan.semakin tinggi tingkat pendidikan seseorang semakin mudah menerima informasi sehingga banyak pula pengetahuan yang dimiliki.

Berdasarkan hasil pengamatan dan penelitian oleh Ibrahim, dkk (2012) diketahui bahwa ada 37 responden dengan tingkat pengetahuan tinggi sebanyak 36 orang $(97,3 \%)$ yang memanfaatkan jamban dan 1 orang $(2,7 \%)$ yang tidak memanfaatkan jamban. Sedangkan dari 38 responden dengan tingkat penegtahuan rendah sebanyak 6 orang $(15,8 \&)$ yang memanfaatkan jamban dan 32 orang $(84,2 \%)$ yang tidak memanfaatkan jamban.

Berdasarkan data jamban sehat dari Puskesmas Bonjeruk Tahun 2017 terdiri dari 4 Dusun,ke empat Dusun tersebut yaitu Dusun Bonjeruk, Dusun
Pengenjek, Dusun Perine, Dusun bunkate, jumlah jamban yang dimiliki oleh Dusun Bonjeruk sebanyak 2.284 jamban Dusun Pengenjek sebanyak 1.884, jamban Dusun Perine sebanyak 1.242, jamban Bunkate sebanyak 825 jamban.

Dan berdasarkan laporan Penyakit diare di posyandu yang bertempat di UPTD Puskesmas Bonjeruk Tahun 2018 dari Bulan Januari-Oktober 2018, jumlah penderita di Wilayah Bunkate dalam jumlah keseluruhannya 60 jiwa,Dusun Bonjeruk jumlah keseluruhannya 217 jiwa,Dusun Perina jumlah penderita diare keseluruhannya 139 jiwa,dan Dusun Pengenjek jumlah penderita diare sebanyak 116 jiwa.Dari beberapa Dusun tersebut terdapat peningkatan jumlan tertinggi diare di wilayah Dusun Bonjeruk dengan 217 jiwa yang mengalami diare,balita yang mengalami diare dari umur 1-12 Bulan laki-laki berjumlah 12 balita perempuan 10 balita, sedangkan pada umur 1-4 Tahun laki laki brjumlah 13 balita perempuan berjumlah 15 balita. Dari jumlah balita keseluruhannya sebanyak 50 balita. Penelitian ini bertujuan melihat hubungan kondisi jamban dengan kejadian diare pada balita di Dusun Bonjeruk wilayah kerja UPTD Puskesmas Bonjeruk Lombok Tengah.

\section{METODE}

Penelitian ini adalah penelitian deskriptif korelasional yang menggunakan pendekatan cross sectional. Populasi penelitian ini adalah semua ibu yang mempunyai balta yang bertempat tinggal di Dusun Bonjeruk Wilayah Kerja UPTD Puskesmas Bonjeruk berjumlah 52 orang di bulan Oktober-November 2018. Sampel pada penelitian ini berjumlah 52 orang dengan menggunakan total sampling. Penelitian ini menggunakan uji statistik korelasi Chi-square untuk melihat hubungan dua 
variable yang ada dengan tingkat kemaknaan 0,05. Instumen yang digunakan untuk mengukur kedua variabel yaitu pedoman observasi dan pedoman wawancara.

\section{HASIL DAN PEMBAHASAN}

\section{Hasil}

a. Distribusi Responden berdasarkan Kondisi Jamban

Tabel 1. Distribusi Responden berdasarkan Kondisi Jamban di Dusun Bonjeruk Wilayah Kerja Puskesmas Bonjeruk

\begin{tabular}{clcc}
\hline No & $\begin{array}{c}\text { Kondisi } \\
\text { Jamban }\end{array}$ & $\begin{array}{c}\text { Frekuensi } \\
(\mathrm{n})\end{array}$ & $\begin{array}{c}\text { Persentase } \\
(\%)\end{array}$ \\
\hline 1 & Sehat & 46 & 88.5 \\
\hline 2 & Tidak sehat & 6 & 11.5 \\
\hline & Total & 52 & 100 \\
\hline
\end{tabular}

b. Distribusi Responden berdasarkan Kejadian Diare

Tabel 2. Distribusi Kejadian Diare pada Balita di Dusun Bonjeruk Wilayah Kerja Puskesmas Bonjeruk

\begin{tabular}{cccc}
\hline No & $\begin{array}{c}\text { Kejadian } \\
\text { Diare }\end{array}$ & Frekuensi & Persentase \\
\hline 1 & Diare & 31 & 59,62 \\
\hline 2 & Tidak Diare & 21 & 40,38 \\
\hline & Total & 52 & 100 \\
\hline
\end{tabular}

c. Hubungan kondisi jamban dengan kejadian diare pada balita di Dusun Bonjeruk Wilayah Kerja Puskesmas Bonjeruk

Tabel 3. Tabel Silang kondisi jamban dengan kejadian diare pada balita di Dusun Bonjeruk Wilayah Kerja Puskesmas Bonjeruk

\begin{tabular}{|c|c|c|c|c|c|c|c|}
\hline \multirow{3}{*}{$\begin{array}{l}\text { Kondisi } \\
\text { Jamban }\end{array}$} & \multicolumn{4}{|c|}{ Kejadian Diare } & \multirow{2}{*}{\multicolumn{2}{|c|}{$\begin{array}{c}\text { Tota } \\
1\end{array}$}} & \multirow{3}{*}{$\begin{array}{c}\text { Exact } \\
\text { Sig. (2- } \\
\text { sided) \& } \\
\text { Alpha } \\
\end{array}$} \\
\hline & \multicolumn{2}{|c|}{ Diare } & \multicolumn{2}{|c|}{ Tidak Diare } & & & \\
\hline & $\mathrm{N}$ & $\%$ & $\mathrm{~N}$ & $\%$ & $\mathrm{~N}$ & $\%$ & \\
\hline Sehat & 26 & $50 \%$ & 20 & $\begin{array}{l}38,46 \\
\%\end{array}$ & 46 & $\begin{array}{l}88,4 \\
6 \%\end{array}$ & 0,001 \\
\hline $\begin{array}{l}\text { Tidak } \\
\text { Sehat }\end{array}$ & 5 & $9,62 \%$ & 1 & $1,92 \%$ & 6 & $\begin{array}{l}11,5 \\
4 \%\end{array}$ & $0,05(\alpha)$ \\
\hline Total & 31 & $59,62 \%$ & 21 & $\begin{array}{l}40,38 \\
\%\end{array}$ & 52 & $\begin{array}{l}100 \\
\%\end{array}$ & \\
\hline
\end{tabular}

\section{Pembahasan}

a. Kondisi Jamban

Berdasarkan hasil penelitian yang ditunjukkan tabel 1, dapat diketahui bahwa ibu yang mempunyai jamban sehat sebanyak 46 orang $(88,5 \%)$ dan ibu yang mempunyai jamban tidak sehat sebanyak 6 orang $(11,5 \%)$. Jamban merupakan fasilitas pembuangan tinja yang efektif untuk memutuskan mata rantai penularan penyakit. Penggunaan jamban tidak hanya nyaman melainkan juga turut melindungi dan meningkatkan kesehatan keluarga dan masyarakat. Dengan bertambahnya jumlah penduduk yang tidak sebanding dengan area pemukiman yang ada, masalah mengenai pembuangan kotoran manusia menjadi meningkat, dilihat dari segi kesehatan masyarakat, masalah pembuangan kotoran manusia merupakan masalah pokok untuk sedini mungkin diatasi (Notoatmodjo, 2005)

Perkembangan penduduk saat ini terkait penggunaan jamban sehat semakin menurun hal ini sejalan dengan hasil penelitian Lidiawati, (2016) dimana penelitiannya menunjukkan dari 65 responden yang penggunaan jamban sehat sebanyak 22 orang $(33,8 \%)$, sedangkan 53 responden penggunaan jamban tidak sehat sebanyak 37 orang $(69,8 \%)$, Hasil analisis statistik dengan uji che square diketahui bahwa ada hubungan yang bermakna antara penggunaan jamban dirumah dengan angka kejadian diare pada balita diwilayah kwerja puskesmas meuraxa.

b. Kejadian Diare

Berdasarkan hasil penelitian yang ditunjukkan tabel 2, dapat diketahui bahwa yang mengalami diare sebanyak 38 responden $(73,1 \%)$ dan yang tidak diare sebanyak 14 responden (26,9\%). Menurut Riskesdas (2007) diare merupakan 
penyakit dimana buang air besar dalam bentuk cair sebanyak 3 kali sehari atau lebih dari normal, terkadang dapat disertai oleh darah, diare sebagai kejadian buang air besar dengan konsistensi lebih cair dari biasanya (Rahmawati, 2013).

Pada tabel 2 dapat diketahui bahwa responden dengan umur 1-12 bulan sebanyak 27 orang $(51,9 \%)$ dan responden dengan umur 13-59 bulan sebanyak 25 orang $(48,1 \%)$. Menurut Suraatmaja (2007) balita dengan usia 1-12 bulan lebih cenderung terkena diare disebabkan oleh makanan balita yang masih tergantung pada Asi, tinggi angka diare pada balita dikarenakan menurunnya daya tahan tubuh/sistem imun terhadap infeksi penyakit terutama penyakit diare (Rahmawati, 2013).

Sejalan dengan penelitian Handayani dan Arsiani (2015) menjelaskan bahwa usia balita merupakan usia rentan terkena penyakit. Hasil penelitiannya menyampaikan bahwa salah satu factor penyebab kejadian diare pada balita 0-59 bulan adalah adanya kepemilikan jamban dan jenis tempat BAB.

c. Analisis hubungan kondisi jamban dengan kejadian diare

Berdasarkan hasil penelitian yang ditunjukkan tabel 3 didapatkan nilai Exact Sig. (2-sided) sebesar 0,001. Nilai Exact Sig. (2-sided) tersebut lebih kecil dari alpha $(0,05)$, hal ini berarti bahwa ada hubungan yang signifikan antara kondisi jamban dengan kejadian diare pada balita.

Hal ini sejalan dengan penelitian yang dilakuka oleh (Rahmawati, 2012) menyatakan ada hubungan kepemilikan jamban dengan kejadian diare pada balita di desa jatisobo kecamatan polokarto kabupaten sukoharjo, universitas muhammadiyah Surakarta. Hal yang sama ditunjukkan oleh Putranti (2013) dimana hasil penelitianya menjelaskan bahwa ada hubungan antara pemanfaatan jamban dengan kejadian diare dari hasil menunjukkan adanya hubungan yang bermakna. Pemanfaatan jamban berpotensi untuk menurunkan risiko terjadinya diare.

Kepemilikan jamban merupakan faktor yang berperan penting terhadap kejadian diare pada balita karena dengan adanya jamban yang sesuai standar kesehatan yang telah ditetapkan oleh pemerintah maka penyakit terutama diare akan terputus mata rantai penularannya (Handayani \& Arsiani, 2015). Hasil yang sama ditunjukkan oleh penelitian yang dilakukan oleh Rahmawati (2012) menjelaskan ada hubungan yang signifikan antara kepatuhan pemakaian jamban terhadap kejadian diare pada balita.

Banyak faktor yang dapat menyebabkan kejadian diare pada balita seperti adanya infeksi yang disebabkan bakteri, virus dan parasit atau adanya gangguan absobsi makanan pada usus (malabsorbsi), alergi, keracunan bahan kimia atau adanya racun yang terkandung dalam makanan, imunodefisiensi yaitu kekebalan tubuh yang menurun serta penyebab lain. Faktor penyebab terjadinya diare akut pada balita ini adalah antara lain faktor lingkungan, tingkat pengetahuan ibu, sosial ekonomi masyarakat dan makanan atau minuman yang di konsumsi (Winamo, 2011).

Menurut hasil penelitian yang dilakukan oleh Fera Novitry, Rizka Agustin (2017). Menunjukkn hasil bahwa Terdapat hubungan yang bermakna antara pendidikan, pengetahuan, sikap, dan pendapatan keluarga dengan kepemilikan jamban, hal yang sama ditunjukkan oleh hasil penelitian yang dilakukan oleh Ikhsan 
Ibrahim dkk (2012) Terdapat hubungan yang bermakna antara pengetahuan, responden dalam pemanfaatan jamban, Hubungan sikap dan tindakan pemanfaatan jamban, Hubungan kondisi jamban dengan tindakan pemanfaatan jamban. Seperti yang diketahui bahwa dampak buruk jamban terhadap penularan penyakit menyangkut transmisi penyakit dari tinja. Berbagai penyakit menular seperti hepatitis A, polio, cholera dan lainnya menrupakan penyakit yang terkait dengan akses penyediaan jamban. Dan sebagai salah satu indicator utama terjadinya pencemaran karena tinja ini adalah bakteri E. Coli sebagaimana diketahui bahwa escherchia coli hidup dalam saluran pencernaan manusia.

Menurut Depkes RI 2005, syarat-syarat jamban sehat adalah pembuangan kotoran yang tidak mengotori tanah permukaan, tidak mengotori air permukaan, tidak mengotori air tanah, memiliki rumah kakus, kakus harus tertutup dan terlindung, lantai sebaiknya semen, dan kotoran tidak terbuka dapat mengurangi kejadian diare karena tidak tersedia media bagi lalat untuk bertelur dan berkembangbiak.

\section{SIMPULAN DAN SARAN}

\section{Simpulan}

1. Kejadian diare di Dusun Bonjeruk wilayah kerja UPTD Puskesmas Bonjeruk Lombok Tengah sebanyak 31 responden $(59,6 \%)$

2. Kondisi jamban di Dusun Bonjeruk wilayah kerja UPTD Puskesmas Bonjeruk Lombok Tengah sebanyak 46 orang $(88.5 \%)$ memiliki jamban sehat

3. Dari hasil uji analisis didapatkan nilai Exact Sig. (2-sided) sebesar 0,001 yang artinya lebih kecil dari alpha $(0,05)$, sehingga dapat dinyatakan bahwa ada hubungan yang signifikan antara variabel kondisi jamban dengan kejadian diare pada balita di Dusun Bonjeruk wilayah kerja UPTD Puskesmas Bonjeruk Lombok Tengah

\section{Saran}

Pihak puskesmas dapat terus untuk melakukan penyuluhan dan pembinaan dalam penangan diare salah satunya dengan penerapan jamban sehat bagi masyarakat untuk menekan angka kejadian diare di wilayah kerjanya 


\section{DAFTAR PUSTAKA}

Amelia, 2014. Ilmu keperawatan Komunitas Pengantar dan Teori buku 1 Whid Ikbal Mubarak, Penerbit Salembar Medika

Depkes RI, 2005. Kesehatan Indonesia dalam Gambar 1996-2005. Jakarta.

Dinas Kesehatan Provinsi Nusa Tenggara Barat. (2017). Profil Kesehatan Provinsi Nusa Tenggara Barat Tahun 2016.

https://www.kemkes.go.id/resources/ download/profil/PROFIL KES PRO VINSI_2016/18_NTB_2016.pdf

Handayani \& Arsiani.(2015).Faktorfaktor yang Mempengaruhi Diare Pada Balita Usia 0-59 Bulan di Puskesmas Gedangan Kecamatan Gedangan Kabupaten Malang Tribhuwana Tunggadewi Malang. Jurnal Unitri. Volume 3, No. 2 Desember 2015.

file:///C:/Users/user/Downloads/7891567-1-PB.pdf

Ibrahim, dkk. 2012. Faktor-Faktor Yang Berhubungan Dengan Pemanfaatan Jamban Di Desa Pintu Langit Jae Kecamatan Padangsidimpuan Angkola Julu. https://media.neliti.com/media/public ations/14418-ID-faktor-faktor-yangberhubungan-dengan-pemanfaatanjamban-di-desa-pintu-langit-ja.pdf

Kemenkes RI. 2011. Situasi Diare di Indonesia. 2011 file:///C:/Users/user/AppData/Local/ Temp/buletin-diare-1.pdf

Kementerian Kesehatan Republik Indonesia. (2015). Profil Kesehatan Indonesia Tahun 2014.J akarta: Kementerian Kesehatan Republik Indonesia

Lidiawati, Meri. 2016. Hubungan Sanitasi Lingkungan Dengan Angka Kejadian Diare pada Balita DiWilayah Kerja Puskesmas
Meuraxa. Jurnal Serambi Saintia. Volume

IV, file:///C:/Users/user/Downloads/Doc uments/85-169-1-SM.pdf

Melviana, dkk. 2014. Hubungan Sanitasi Jamban Dan Air Bersih Dengan Kejadian Diare Pada Balita Di Kelurahan Terjun Kecamatan Medan Marelan Kota Medan Tahun 2014. https://media.neliti.com/media/public ations/14517-ID-hubungan-sanitasijamban-dan-air-bersih-dengankejadian-diare-pada-balita-di-kel.pdf Notoatmojo, Soekidjo. Ilmu dan seni kesehatan masyarakat . 2005. Jakarta : Rineka Cipta

Novitry \& Agustin. 2017. Determinan Kepemilikan Jamban Sehat di Desa Sukomulyo Martapura Palembang. Aisyah: Jurnal Ilmu Kesehatan 2 (2), 107-116.

file://C:/Users/user/Downloads/51197-2-PB.pdf

Putranti \& Sulistyorini. 2013. Hubungan Antara Kepemilikan Jamban dengan Kejadian Diare di Desa Karangagung Kecamatan Palang Kabupaten Tuban. Jurnal Kesling Volume 7. No. 1. Universitas Airlangga. file:///C:/Users/user/Downloads/Doc uments/keslingb03cb54364full.pdf

Rahmawati, Fajriana Ayu. 2013. Hubungan Kepemilikan Jamban Dengan Kejadian Diare Pada Balita di Desa Jatisobo Kecamatan Polokarto Kabupaten Sukoharjo. http://eprints.ums.ac.id/id/eprint/223 01

WHO. 2014. Progres Sanitasi dan Air Minum -Progress on Sanitation and Drinking-Water: Update. Geneva: WHO 2010

Winamo, 2011, Ilmu keperawatan Komunitas Pengantar dan Teori buku 1 Whid Ikbal Mubarak, Penerbit Salembar Medika. 